\title{
Nursing counseling decreases symptomatology and relapses in pediatric patients with allergic rhinitis
}

\author{
Laura Solís-Flores ${ }^{1}$, Rosalinda Acuña-Rojas ${ }^{2}$, Leobardo López-Medina ${ }^{3 *}$ and Guillermo Meléndez-Mier ${ }^{4}$ \\ ${ }^{1}$ Department of Education; ${ }^{2}$ Pediatrics service; ${ }^{3}$ Unit 309 of Allergies; ${ }^{4}$ Department of Project Registration and Monitoring. Hospital General de \\ México Dr. Eduardo Liceaga, Mexico City, Mexico
}

\begin{abstract}
Background: Allergic rhinitis (AR) is considered to be a public health problem. Therefore, it is essential to test health education strategies such as nursing counseling (NC) aimed at population groups such as children with allergic rhinitis and their tutors. This study aimed to measure the health benefits of children with this disease for a year. Methods: It is a longitudinal, randomized, comparative study with a sample of 100 pediatric patients of both sexes, aged 6 to 12 years, with a diagnosis of allergic rhinitis, with counseling (study group) and without counseling (control group). In both groups, an informed consent letter signed by both tutors was applied, in addition to knowledge and assessment forms, the second included a scale of symptomatology and a Morisky-Green scale (adherence to treatment). Children in the study group received an intervention based on personalized education, teaching material, support from a multidisciplinary group if necessary (physician, dermatologist, and psychologist). The control group received usual care. In both groups, telephone follow-up was used, which allowed identification of the number of relapses in one year. Results: The Wilcoxon rank-sum test (Mann-Whitney) was used to compare the results, so the presence of relapses in the control group was statistically significant compared to the study group. Conclusions: It was found that the pediatric population that receives NC has improved control of symptomatology and decrease of relapses per year.
\end{abstract}

Key words: Relapses. Symptomatology. Allergic rhinitis. Asthma. Health education. Nursing counseling.

\section{La consejería de enfermería disminuye la sintomatología y recaídas en pacientes pediátricos con rinitis alérgica}

\section{Resumen}

Introducción: La rinitis alérgica (RA) es considerada como un problema de salud pública, por lo tanto, es indispensable poner a prueba estrategias de educación para la salud como la consejería de enfermería (CE) dirigida a grupos poblacionales como niños con rinitis alérgica y sus tutores. Este trabajo tuvo como objetivo medir durante un año los beneficios en la salud de población infantil con esta enfermedad. Métodos: Estudio longitudinal, aleatorio, comparativo, con una muestra de 100 pacientes pediátricos de ambos sexos, con edades de 6 a 12 años, con diagnóstico de rinitis alérgica, con consejería (grupo estudio) y sin consejería (grupo control). En ambos grupos se aplicó carta de consentimiento informadofirmada por ambos tutores, además de cédulas de conocimiento y de valoración; la segunda incluyó escala de sintomatología y de

\section{Correspondence:}

*Leobardo López-Medina

E-mail: leobardo1956@ hotmail.com www.bmhim.com 
Morisky Green (adherencia al tratamiento). Los niños del grupo estudio recibieron intervención basada en educación personalizada, material didáctico, apoyo del grupo multidisciplinario en caso necesario (médico, dermatólogo y psicólogo). El grupo control recibió atención habitual. En ambos grupos se hizo seguimiento vía telefónica, lo que permitió identificar el número de recaídas en un año. Resultados: Para la comparación de los resultados se aplicó la prueba de Wilcoxon ranksum (Mann-Whitney), por lo que se encontró estadísticamente significativa la presencia de recaídas en el grupo control comparado con el grupo estudio. Conclusiones: Se encontró que la población infantil que recibe $C E$, tiene como beneficio mejor control de la sintomatología y disminución de recaídas al año.

Palabras clave: Recaídas. Sintomatología. Rinitis alérgica. Asma. Educación para la salud. Consejería de enfermería.

\section{Introduction}

The World Health Organization stated that the fundamental objective of therapeutic education is to "help the patient and his primary caregiver to acquire the necessary resources to manage a chronic disease optimally." It is a continuous, dynamic and adapted process, in which the following is achieved: 1) empowerment of the patient and 2) changes in conducts and attitudes'.

The Hospital General de México Dr. Eduardo Liceaga (HGMEL) has been a pioneer in establishing nursing counseling as a strategy for therapeutic education since 2008, with the objective of promoting adherence to pharmacologic and non-pharmacologic treatments.

An assigned nurse for educating can be easily accessible $^{2}$ and can contribute to the resolution of the patient's doubts since part of his practice is to assess the needs for health education. For that reason, nursing counseling (NC) directed at children with allergic rhinitis $(\mathrm{AR})$ is a personalized health education tool, with actions to empower the child in his self-care. This counseling places the child at the central axis of attention by a multidisciplinary team and his caregivers, with the goals of offering alternatives for his care, avoiding complications and limiting concomitant diseases. Its approach spans from the transcultural and the specific resources of each patient's family, which makes it an area of opportunity to assess and accompany, being a warm and genuine mirror.

AR is a global public health problem associated with concomitant diseases that are increasing; it is estimated that 600 million people in the world suffer from $\mathrm{AR}^{3-6}$.

In Mexico, around $4.6 \%$ of children have AR (ISAC study F-III) ${ }^{7}$. The HGMEL reported it as the main reason for consultation in 411 schoolchildren (181 girls and 230 boys) at the pediatric outpatient clinic during the first trimester of 2016. In the same hospital, 958 children between 5 and 15 years (378 girls and 580 boys) were treated in the Allergy service during the same trimester, with a predominance of male gender ${ }^{8,9}$. Pharmacologic treatments usually lack personalized education regarding specific topics ${ }^{10}$. Relapses (reappearance of a certain disease in a subject that has not yet achieved a complete cure $)^{11}$ are also due to the lack of knowledge of the disease prevention, and care ${ }^{12-14}$. Treatments are usually long and expensive, which can generate frustration and abandonment by the patient and his caregiver ${ }^{10}$.

For all the above, it is essential to assess the obtained results of the nursing intervention plan based on personalized counseling directed to the pediatric patient with allergic rhinitis and his family.

\section{Methods}

A randomized clinical trial was conducted with 100 pediatric patients of both genders, with ages between 6 and 12 years, and a recent diagnosis of AR of less than a month, without any educational intervention, with pharmacological treatment of less than a month $A$ randomized table was constructed in Excel, with counseling (study group) and no counseling (control group). In both groups, informed consent was obtained from both parents (approved by the ethics in research committee) and consent by the minors.

Two data collection instruments were designed: a knowledge form consisting of ten items that assessed the need for specific care, and a form for the detection of health needs. The latter integrated the Morisky-Green ${ }^{15}$ scale to assess adherence to medications and a questionnaire of symptoms ${ }^{16}$ selected by the criteria and clarity to identify symptom severity (absent $=0$ points, mild $=1-7$ points, moderate $=8-14$ points, severe $=15-21$ points, very severe $=22-28$ points). The questionnaire allows for identification of symptoms such as nasal congestion, sneezing, rhinorrhea, redeye and epiphora, nasal pruritus, ocular pruritus and otic or oropharyngeal pruritus.

Both instruments were tested through a pilot study of 35 and 35 data collection instruments in the pediatrics service, in which reliability of 0.76 in the knowledge 
questionnaire and 0.81 in the form for detection of health needs was observed using a Cronbach's alpha.

Children from the study group received a medical consult, an education-based intervention (EBI), and follow-up. They were given teaching material, support of the multidisciplinary group, if necessary, assessment by a physician, dermatologist, and psychologist, and telephone follow-up (patients had a telephone number to express their doubts if necessary).

The control group had periodic medical visits and phone calls with the goal of identifying the health status of the children and the number of relapses in a year.

Intervention procedure:

1. Application of the informed consent, in which it was clarified what their participation consisted of and that the children could belong to either of the two groups.

2. Both groups had between five and seven consultations. Only the study group (SG) received counseling in addition to medical consultations.

3. For the study group, different topics that were considered essential to decrease risk in children were planned. For example, orientation to the child to participate in his medical consultation (to lose the fear and to interact with doubts and events experienced with the medications, application of the medications and their possible side effects, correct use of the devices and rescue medications). Also, administration of immunotherapy if necessary, allergens for which the child was sensitive, prevention of relapses and symptomatology, and alarm symptoms that would require a visit to the emergency department due to exacerbations of their symptomatology. Nasal hygiene, cleanliness of the house and room, personal care (routines at school and home, healthy habits), hand hygiene, use of efficient protective barriers (face masks) were included as well. If necessary, emotional containment was provided to the mother and especially to the child. Smokers in the house were educated, and a consultation with the tobacco clinic was indicated.

Health education was done through games, mimics, memory games, and group integration, with the objective that the children discussed their experiences with the disease, their adaptation, to learn through others' significant experiences, notes were written to express doubts and questions at their next consultation or phone call.

4. Participation of the multidisciplinary team:

The counselor identified a health issue and referred it the required specialists, communicating them with the attending physician for follow-up with the support of the primary caregiver and the child. The time for nursing counseling was 30 minutes to an hour and a half. Children that received counseling could attend in case of any doubts; in case of relapses they were referred to the attending physician and home care was adjusted.

Phone calls: phone calls had a duration of 15-20 minutes, and they were done with the goal to identify the health status of the children and to clarify their doubts.

Control group (CG): patients in this group oversaw their own medical control and, if necessary, they could express their doubts to the counseling nurse, who referred them to their attending physician for a medical consultation. If any risk was identified, they were suggested to ask their physician (Figure 1).

\section{Statistical analysis}

A $X^{2}$ and contingency tables were used for the comparison of results between groups with categorical variables (such as symptoms).

\section{Results}

Children in the $C G$ and the $S G$ had a mean age of 8.8 and 8.6 , respectively; the age of the primary caregiver was 37.3 for those in the $C G$ and 38.3 for those in the SG. The mode of schooling corresponded to a fourth grade for the $C G$ and third grade in the $S G$. Regarding gender of the children, there was a predominance of the male gender in both groups ( $56 \%$ for the CG and $62 \%$ for the SG). In $90 \%$ of the cases in each group, the primary caregiver role corresponded to the mother; likewise, his/her occupation was the home in $66 \%$ in both groups. Fifty percent of the patients lived in Mexico City in the CG an $46 \%$ in the SG. Cases of children with atopic tendency were detected in 17.5\% of the $C G$ and $13 \%$ of the SG (Tables 1 and 1.1).

In the CG, children presented with concomitant diseases: $8 \%$ with angioedema, urticaria, dermatitis, bronchial hyperreactivity; $9 \%$ with sinusitis, and $56 \%$ with asthma (diagnosed during the first trimester of the intervention). The SG presented $2 \%$ of pharyngitis, angioedema, urticaria; $8 \%$ with bronchial hyperreactivity, $10 \%$ with dermatitis and adenoiditis, $32 \%$ with sinusitis, and $38 \%$ with asthma.

The most common allergens were mites, ash tree, oak, house dust, California pepper tree, Ligustrum, quelite, amaranth, cockroach, mesquite, birch. The study group, like the control group, was unaware of the allergen to which they were sensitive. At the end of 


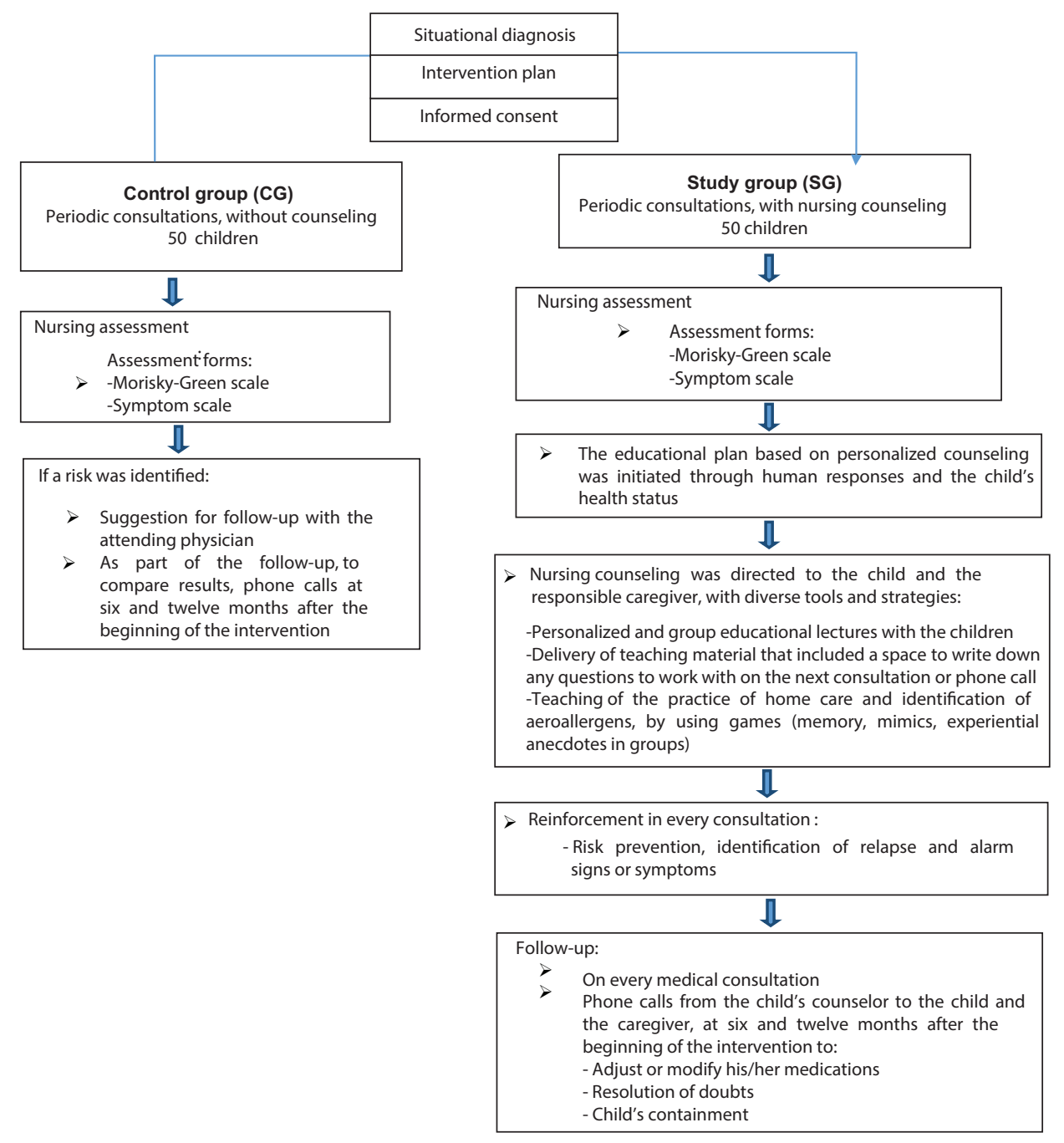

Figure 1. Nursing intervention based on personalized counseling. Patients' follow-up.

Table 1. Sociodemographic data

\begin{tabular}{l|c|c|}
\hline Variables* & Control group & Study group \\
\hline Age of the patient & 8.8 & 8.6 \\
\hline $\begin{array}{l}\text { Age of the primary } \\
\text { caregiver }\end{array}$ & 37.3 & 38.3 \\
\hline \begin{tabular}{l} 
Children's schooling (x) \\
\hline *Mean
\end{tabular} & Fourth grade & Third grade \\
\hline
\end{tabular}

the intervention, both groups had a better knowledge of these allergens (Figure 2).

The result is statistically significant according to the group. At the end of the intervention, children in the control group had increased symptomatology.
A statistical significance was detected using the $X^{2}$ test $(p=0.0001)$ (Table 2).

Children in the study group had lesser relapses during the year of the nursing educational intervention based on personalized counseling (Table 3).

Adherence to pharmacological treatment was statistically significant in the SG, with a Pearson's $r$, $(p=0.000)$. The $S G$ showed a greater adherence to pharmacological treatment (Table 4).

\section{Discussion}

$A R$ is a chronic disease that requires adequate time to provide patient care accordingly to his needs, given that he undergoes stages of denial, acceptance, adherence and, lastly, self-control. 


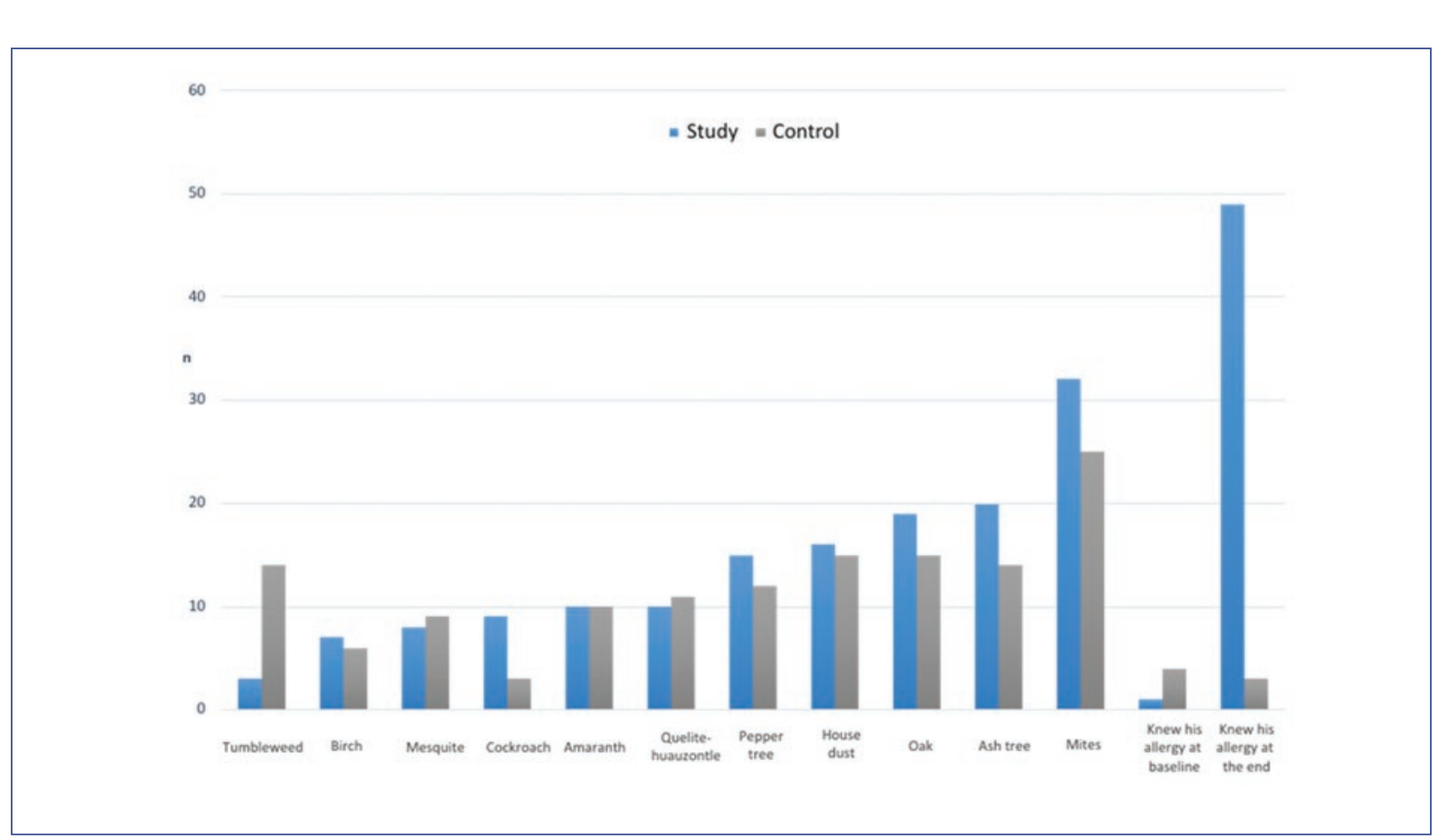

Figure 2. Most predominant allergens in the studied population.

Source: Assessment form applied to the studied population during 2012.

Table 1. 1. Sociodemographic data

\begin{tabular}{|l|c|c|c|c|}
\hline \multirow{2}{*}{ Variable } & \multicolumn{2}{|c|}{$\begin{array}{c}\text { Control } \\
\text { group (CG) }\end{array}$} & \multicolumn{2}{c|}{$\begin{array}{c}\text { Study } \\
\text { group (SG) }\end{array}$} \\
\cline { 2 - 5 } & $\mathbf{n}$ & $\%$ & $\mathbf{n}$ & $\%$ \\
\hline $\begin{array}{l}\text { Gender } \\
\text { Male } \\
\text { Female }\end{array}$ & 28 & 56 & 31 & 62 \\
\hline $\begin{array}{l}\text { Mother as a primary } \\
\text { caregiver }\end{array}$ & 22 & 44 & 19 & 38 \\
\hline $\begin{array}{l}\text { Occupation of } \\
\text { the guardian } \\
\text { (home) }\end{array}$ & 35 & 90 & 45 & 90 \\
\hline $\begin{array}{l}\text { Place of residence } \\
\text { Mexico City } \\
\text { State of Mexico }\end{array}$ & 25 & 50 & 23 & 46 \\
\hline \begin{tabular}{l} 
Atopic tendency \\
\hline
\end{tabular} & 35 & 17.5 & 26 & 13 \\
\hline
\end{tabular}

Education is an indissociable practice of treatment in the patient with asthma ${ }^{1}$, and allergic rhinitis must be included in this statement. Close collaboration with the family and the child is required to achieve transference of the knowledge from the nurse; besides, motivation should be the main motor driving knowledge receptivity, but before this, acceptance of the disease is required.
After having performed a systematic review of the efficacy of therapeutic education in chronic respiratory diseases, it was detected that educational interventions show statistically significant benefits of a total of 30 randomized clinical trials. For that reason, the authors of these studied propose conducting more randomized clinical trials with a strict methodology that adhere to the WHO's concept to assess its effectiveness, the duration of the intervention and the most appropriate health care professional to provide a better patient education $^{12}$. For this action, it is important to start with a situational diagnosis of the population that attends the Allergy service, which allows recognition of the importance of the education that the nurse provides to the child and his primary caregiver; nursing professionals are a key element for this type of interventions ${ }^{1}$. In this case, what is important is the educational intervention plan based on NC.

There were benefits with the educational intervention based on NC directed at children with AR and their relatives; there are extremely valuable plans that are similar to this educational intervention ${ }^{17}$, the difference is that there are no reports of the results. In this study, patients were followed-up for a year, which allowed identification of the benefits of the nursing educational intervention. 
Table 2. Results of the symptomatology scale at baseline and the end of the intervention

\begin{tabular}{|c|c|c|c|c|c|c|}
\hline \multirow[t]{2}{*}{ Score on the symptomatology scale } & \multicolumn{2}{|c|}{ Baseline } & \multirow[t]{2}{*}{$\mathbf{p}$} & \multicolumn{2}{|c|}{ End } & \multirow[t]{2}{*}{ p } \\
\hline & Study group & Control group & & Study group & Control Grop & \\
\hline Absent & 0 & 2 & \multirow[t]{5}{*}{0.469} & 7 & 5 & \multirow{5}{*}{ 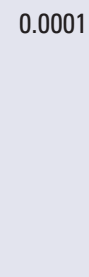 } \\
\hline 1-7 points (mild) & 15 & 15 & & 39 & 20 & \\
\hline 8-14 points (moderate) & 28 & 27 & & 4 & 17 & \\
\hline 15-21 points (severe) & 1 & 6 & & 0 & 8 & \\
\hline 22-28 points (very severe) & 0 & 0 & & 0 & 0 & \\
\hline Table 3. Number of relapses a & e and & & & & & 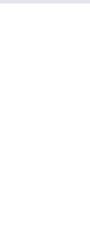 \\
\hline
\end{tabular}

\begin{tabular}{|c|c|c|c|c|c|c|}
\hline \multirow[t]{2}{*}{ Number of relapses } & \multicolumn{2}{|c|}{ Baseline* } & \multirow[t]{2}{*}{ p } & \multicolumn{2}{|c|}{ End } & \multirow[t]{2}{*}{ p } \\
\hline & Study group & Control group & & Study group & $\begin{array}{c}\text { Control } \\
\text { group }\end{array}$ & \\
\hline$>5$ times & 15 & 13 & \multirow[t]{6}{*}{0.069} & 0 & 4 & \multirow{6}{*}{ 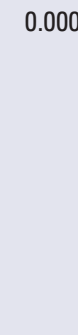 } \\
\hline 4 times & 9 & 4 & & 0 & 0 & \\
\hline 3 times & 6 & 19 & & 0 & 7 & \\
\hline 2 times & 10 & 6 & & 1 & 11 & \\
\hline 1 time & 8 & 7 & & 18 & 15 & \\
\hline None & 2 & 1 & & 31 & 13 & \\
\hline
\end{tabular}

*p, statistical significance, using a Pearson's $r$.

The response of the primary caregiver regarding the number of relapses presented by children in the previous year was considered as a baseline assessmen

Table 4. Adherence to pharmacological treatment measured by the Morisky-Green scale

\begin{tabular}{|c|c|c|c|c|c|c|}
\hline \multirow[t]{2}{*}{$\begin{array}{l}\text { Adherence to treatment } \\
\text { (Morisky-Green) }\end{array}$} & \multicolumn{2}{|c|}{$\begin{array}{c}\text { Baseline } \\
\text { Morisky } 1\end{array}$} & \multirow[t]{2}{*}{$\mathbf{p}$} & \multicolumn{2}{|c|}{$\begin{array}{c}\text { Final } \\
\text { Morisky } 2\end{array}$} & \multirow[t]{2}{*}{$\mathbf{p}$} \\
\hline & Study group & Control group & & Study groups & Control groups & \\
\hline High adherence to treatment & 5 & 2 & \multirow[t]{3}{*}{0.165} & 47 & 15 & 0.000 \\
\hline $\begin{array}{l}\text { Intermediate adherence to } \\
\text { treatment }\end{array}$ & 34 & 42 & & 3 & 27 & है \\
\hline Low adherence to treatment & 11 & 6 & & 0 & 8 & $\because$ \\
\hline \multicolumn{3}{|c|}{${ }^{*} p$, statistical significance, using a Pearson's $r$} & & & & $\begin{array}{l}\frac{-}{0} \\
\frac{\partial}{a} \\
\frac{n}{c} \\
\frac{n}{f}\end{array}$ \\
\hline
\end{tabular}

It has been found that education must be a part of the treatment of children ${ }^{18}$. The nurse directed the educational plan that was assessed during a year based on a warm, respectful and transcultural accompaniment, which was redirected through human responses and the children's health status. A meaningful experience was promoted so the child could assume the consequences of his actions, all of this supported by a relationship based on trust and open and assertive communication with clear and flexible boundaries. 
When necessary, a second option for the child to choose and adapt to was proposed. There were agreements for his benefit with the multidisciplinary team. Benefits with the NC plan were observed: relapses and symptoms decreased, the children were able to recognize situations with risk of provoking relapses and adhere to pharmacologic treatment by learning the importance of taking their medication (Table 4).

It was essential to empower the child by direct and active participation in the pharmacologic and non-pharmacologic treatment in self-control of the disease to achieve these results because most of the risk factors are modifiable ${ }^{19}$.

An important factor for therapeutic compliance is the perception and adequate knowledge of the disease to early recognize worsening symptoms and, therefore, the scheduled treatment plans ${ }^{20}$. Consequently, emergency department visits caused by relapses or the presence of severe symptoms in children decreased. A recent study in Mexico found that $93 \%$ of patients with AR reported that nasal symptoms were present at least four days a week and $73 \%$ of asthmatics reported having bronchial symptoms at least twice a week. Although $93 \%$ of the patients with asthma, rhinitis or both had been prescribed a pharmacological treatment, only $35 \%$ used it with a frequency of at least five days ${ }^{21}$. In this case, the educational intervention group achieved a decrease in symptomatology (Table 2).

Other studies describe the behavior of the disease; however, they do not show convincing results and, especially from educational interventions derived from randomized clinical trials such as this one, which have a direct impact in the children's health status ${ }^{22,23}$.

Success relied upon continuous, patient and family-centered, therapeutic education, which led to the satisfactory results for the group that received NC by having fewer relapses when compared to the control group.

Cited by Valverde in his IV Course for health educators, the specific educational plan allows a decrease in the presence of $\mathrm{R} 1$ relapses in the population (defined as the recurrent experience of the disease that is considered to be controlled. It manifests with the controlled symptoms due to exposure to allergens for which the patient is sensitive and can be caused by practicing risk behaviors). Education for self-management reduces the use of resources, health costs, and improves the quality of life for the patient. Nursing plays a fundamental role in the education of the asthmatic child and other health professionals; it is suggested that one of the greatest advances in asthma care in primary care teams has been the development of nursing consultations ${ }^{24-26}$.
Giving importance to the child as a participant in his care has repercussions by decreasing relapses. Regarding the transcultural aspects of the educational plan $^{27}$, there was a difference between both groups because NC was provided in a personalized manner, which improves treatment adherence and, thus, decreases relapses.

Effective, assertive, and open communication is necessary, as well as working together with the multidisciplinary team. An open phone line is important for the success of NC health educational programs. By educating the family and the child, disease management improves and, therefore, relapses decrease (Table 3).

Treatment of AR has three main aspects: patient education, pharmacotherapy, and allergen-specific immunotherapy ${ }^{28}$. As a fourth, we propose a nursing intervention to give continuity to pharmacological (adequate use of medications and devices) and non-pharmacological treatment, and far as possible to conduct continuous assessments of the children, since there are existing clinical guidelines for consultation ${ }^{7,29}$.

Health education based on scientific evidence and personalization of the educational plan that includes essential topics in children with AR is fundamental, as well as the knowledge of the disease, its management, control and prevention of the avoidable, without forgetting the emotional aspects concerning the child and his caregiver ${ }^{30}$.

Personalized nursing counseling is an effective strategy for the pediatric patient education and his/her responsible relative, to achieve good rhinitis management. With an integral education, the child is reinforced to be the protagonist in his pharmacological and non-pharmacological treatment (adherence to treatment), since he will be able to recognize the importance of his medication, and alarm signs or symptoms that could lead to relapses. NC favors the child's health by significantly decreasing the symptoms of the disease and the need for emergency services when the symptomatology is exacerbated, which sometimes lead to relapses.

The key is to apply this therapeutic education integrally without underestimating the child's ability for self-care.

\section{Ethical disclosures}

Protection of human and animal subjects. The authors declare that no experiments were performed on humans or animals for this study. 
Confidentiality of data. The authors declare that they have followed the protocols of their work center on the publication of patient data.

Right to privacy and informed consent. The authors declare that no patient data appear in this article.

\section{Conflicts of interest}

The authors declare no conflicts of interest.

\section{References}

1. Cano DR, Useros OA, Muñoz HE. Eficacia de los programas de educación terapéutica y de rehabilitación respiratoria en el paciente con asma. Arch Bronconeumol. 2010; 46:600-6.

2. Wooler $E$. The role of the nurse in paediatric asthma management. Paediatr Respir Rev. 2001;2:76-81. Available at: https://www.ncbi.nlm. nih.gov/pubmed/16263484.

3. Huerta LJ. La Organización Mundial de Alergia (WAO) destaca el impacto en todo el mundo. Alerg, Asm Inmunol Pediatr. 2008; 17:4. Available at: http://www.medigraphic.com/pdfs/alergia/al-2008/al081a.pdf.

4. López PG, Morfin MBM, Huerta LJ, Mejía CF, López LJ, Aguilar G, et al. Prevalencia de las enfermedades alérgicas en la Ciudad de México. Rev Alerg Mex. 2009; 56:72-9. Available at: http://www.imbiomed.com.mx/1/1/ articulos.php? method=showDetail\&id_articulo=57718\&id_seccion $=64 \&$ id_ejemplar=5843\&id_revista $=12$.

5. Comité Nacional de Alergia, Comité Nacional de Neumología, Comité de Otorrinolaringología de SAP Filial Córdoba. Consenso Nacional de Rinitis Alérgica en Pediatría. Arch Argent Pediatr. 2009; 107:67-81. Available at: http://www.scielo.org.ar/pdf/aap/v107n1/v107n1a15.pdf.

6. Soto AS, Partida GA, Romero PM, Martínez VA, Díaz GL, Bautista GS. Análisis descriptivo de la sensibilización a alérgenos en una población pediátrica. Alerg, Asm Inmunol Pediatr. 2015; 24: 40-53. Available at: http://www.medigraphic.com/pdfs/alergia/al-2015/al152b.pdf.

7. ARIA México 2014. Adaptación de la guía de práctica clínica ARIA 2010 para México. Metodología ADAPTE. Rev Alergia Mex. 2014; 61: S3-116. Available at: http://revistaalergia.mx/ojs/index.php/ram/article/view/52/94.

8. Hospital General de México. Dirección de planeación y desarrollo de sistemas administrativos. Cuadernos estadísticos Pediatría 505. Enero-Marzo 2016. Available at: http://www.hgm.salud.gob.mx/interior/noticias dia.html.

9. Hospital General de México. Dirección de planeación y desarrollo de sistemas administrativos. Cuadernos estadísticos Alergias 309. Enero-Marzo. Available at: http://www.hgm.salud.gob.mx/interior/noticias_ dia.html.

10. Castillo AIY, Cogollo MZ, Adines ML, Campo ML, Galvis MI, Pérez CD, et al. Practicas alternativas de cuidado para asma, por padres de niños atendidos en un hospital de Cartagena. Rev Fac Cienc Salud. 2012; 9:15-22. Available at: http://revistas.unimagdalena.edu.co/index.php/duazary/article/viewFile/184/163.

11. Doctissimo.com.mx [Internet]. Diccionario de medicina Vox. Date accessed: April 12, 2017. Available at: http://www.doctissimo.com/mx/salud/ diccionario-medico/recaida.

12. Casanova LA. Eficacia de la educación terapéutica en las enfermedades respiratorias crónicas: revisión sistemática [tesis]. Alcalá de Henares: Universidad de Alcalá; 2013. Available at: http://dspace.uah.es/dspace/ bitstream/handle/10017/19748/TFG_Casanova_Lozano_2013.pdf?sequence $=1$.

13. Romero MSZ. Factores desencadenantes en una crisis asmática guía de prevención en el Hospital Roberto Gilbert Elizalde periodo 2014 [te- sis]. Guayaquil: Universidad de Guayaquil; 2015. Available at: http://repositorio.ug.edu.ec/bitstream/redug/10930/1/tesis\%20crisis.pdf.

14. Curbelo N, Pinchack C, Gutiérrez S. Conocimiento del asma enfermedad por parte de los padres de niños asmáticos. Arch Pediatr Urug. 2010; 81:225-30. Available at: http://www.scielo.edu.uy/pdf/adp/v81n4/v81n4a02. pdf.

15. Ben JA, Cristina Rolim NC, Serrate MS. Teste de Morisky-Green e Brief [Medication Questionnaire para avaliar adesão a medicamentos]. Rev Saúde Púb. 2012; 54:102-8. Available at: http://www.scielosp.org/pdf/rsp/ v46n2/3357.pdf.

16. Muciño HMI, Macías RH, Cruz RAM, Macedo RC, Cruz RM, Macedo RC, et al. Evaluación de la calidad de vida en pacientes con rinitis alérgica. An Orl Mex. 2009; 54:102-8. Available at: http://www.medigraphic.com/ pdfs/anaotomex/aom-2009/aom093d.pdf.

17. Sistema General de Seguridad Social en Salud Colombia Guía Completa. Asociación Colombiana de Neumología Pediátrica. Guía de práctica clínica (GPC) para el diagnóstico, atención integral y seguimiento de niños y niñas con diagnóstico de asma. Bogotá: MinSalud; 2013. pp: 17-151. Available at: http://www.globalasthmanetwork.org/management/ guides/colombia/GPC_Comp_Asma.pdf

18. Callén BM, Asensi MM, Fernández OC. Manejo Integral del Asma en Atención Primaria. En: AEPap ed. Curso de actualización pediatría. Madrid: Exlibris ediciones; 2012. pp 379-88.

19. Varona PP, Fabre OD, Venero FS, Suárez MR, Molina EE, Romero PM Rinitis alérgica, prevalencia y factores de riesgo en adolescentes cubanos. Rev Cubana Hig Epidemiol. 2014; 52:330-45. Available at: http:// bvs.sld.cu/revistas/hie/vol52_3_14/hig06314.htm.

20. Figueredo MM, Fabré OD, Coutin MG, Del Arco PA. Evaluación del impacto de un programa educativo en algunos factores emocionales de niños asmáticos y sus padres. Rev Alergia Mex. 2011; 58:155-61. Available at: http://www.imbiomed.com.mx/1/1/articulos.php?method=showDetail\&id articulo $=80639 \&$ id seccion $=64 \&$ id ejemplar=7971\&id revista $=12$.

21. Sánchez J, Estarita J, Salemi C. Efecto de la rinitis y el asma en el ausentismo y rendimiento laboral y escolar en una población del trópico latinoamericano. Rev Alerg Mex. 2016; 63:32-40. Available at: http://revistaalergia.mx/ojs/index.php/ram/article/view/132/291.

22. Hernández VM, Morfin MBM, López PG, Huerta LJ. Características clínicas de niños asmáticos mexicanos en un hospital pediátrico de tercer nivel de atención. Acta Pediatr Mex. 2011; 32:202-8. Available at: http:// www.medigraphic.com/pdfs/actpedmex/apm-2011/apm114c.pdf.

23. De La Vega PT, Pérez MV Bezos ML. Factores de riesgo de asma bronquial en niños y su relación con la severidad de las manifestaciones clínicas. Rev Cubana Med Gen Integr. 2010; 26:190-214. Available at: http://scielo.sld.cu/scielo.php?script=sci_arttext\&pi$d=S 0864-21252010000200002$

24. Valverde MJ. IV Curso para educadores en asma. Interés de la educación terapéutica en el asma. Tenerife, España; 2007. pp. 5-12. Available at: http://www.neumoped.org/docs/IVCurso EducadoresASMA2007.pdf.

25. Fasciglione MP, Castañeiras CE. El componente educativo en el abordaje integral del asma bronquial. J Bras Pneumol. 2010; 36:252-9. Available at: http://www.scielo.br/scielo.php?script=sci_arttext\&pi$d=S 1806-37132010000200015$

26. Rodríguez FO, Torregrosa BM. Educando en asma. Rev Pediatr Aten Primaria. 2011;13:215-21.

27. Ortega CC, Pellegrini BJ. Asma: educación sanitaria, autocontrol y medidas preventivas. Pediatr Integral. 2012; XVI:141-8. Available at: http:// www.pediatriaintegral.es/wp-content/uploads/2012/05/141-148-Educacion-asma.pdf.

28. Secretaría de Salud. Manual de Enfermedades Respiratorias 2012. Prevención, diagnóstico y tratamiento. Ciudad de México; 2012. pp. 7-111.

29. García P, Cayo II. Guía de práctica clínica 4. Sevilla: Consejería de Salud de Andalucía; 2012. Available at: http://www.juntadeandalucia.es/ salud/export/sites/csalud/galerias/documentos/p_3_p_3_procesos_asistenciales_integrados/asma/asma.pdf.

30. Rubio ZE, Pérez SG, Conde HJ, Blanco PA. Diferencias conductuales y emocionales entre grupos de enfermos crónicos infanto-juveniles. Anuario de Psicología Clínica y de la Salud. 2010; 6:23-34. Available at: http:// institucional.us.es/apcs/doc/APCS 6 esp 23-34.pdf. 